\title{
Photosynthetic performance of contrasting Jatropha curcas genotypes during the flowering and fruiting stages
}

\author{
Gisele Pereira Domiciano(1), Adilson Kenji Kobayashi(2), \\ Hugo Bruno Correa Molinari(2), Bruno Galveas Laviola ${ }^{(2)}$ and Alexandre Alonso Alves ${ }^{(2)}$
}

(1)Universidade de Brasília, Departamento de Fitopatologia, Campus Universitário Darcy Ribeiro, CEP 70910-900 Brasília, DF, Brazil. E-mail:
gpdomiciano@yahoo.com.br ${ }^{(2)}$ Embrapa Agroenergia, Parque Estação Biológica, Avenida W3 Norte (Final), CEP 70770-901 Brasília, DF,
Brazil. E-mail: adilson.kobayashi@embrapa.br, hugo.molinari@embrapa.br, bruno.laviola@embrapa.br, alexandre.alonso@embrapa.br

Abstract - The objective of this work was to evaluate physiological processes in contrasting physic nut (Jatropha curcas) genotypes during the flowering and fruiting stages. Gas exchange parameters were measured using an infrared gas analyzer, and morphological traits were evaluated during each stage under natural conditions, in a randomized complete block design with five replicates. Differences in yield between $J$. curcas accessions were not related to photosynthetic performance, but rather to the number of inflorescences and female flowers, which are genetically determined. Moreover, the net $\mathrm{CO}_{2}$ assimilation was equivalent in both genotypes, although they produced different amount of fruit. The genotypes differed consistently in terms of carboxylation efficiency and ribulose bisphosphate regeneration. Finally, J. curcas branch growth is not impaired by the increased sink strength during fruiting, and fruit may have been actually exerting a positive effect on the net $\mathrm{CO}_{2}$ assimilation, which may have enabled plants to maintain growth while producing flowers and fruits.

Index terms: Jatropha curcas, biodiesel, carboxylation efficiency, gas exchange, photosynthetic capacity.

\section{Desempenho fotossintético de genótipos contrastantes de pinhão-manso durante estádios de florescimento e frutificação}

\begin{abstract}
Resumo - O objetivo deste trabalho foi avaliar processos fisiológicos em genótipos contrastantes de pinhão-manso (Jatropha curcas), durante as fases de florescimento e frutificação. As trocas gasosas foram mensuradas com analisador de gás por infravermelho, e as características morfológicas foram avaliadas em cada fase sob condições naturais, em delineamento de blocos ao acaso, com cinco repetições. As diferenças no rendimento entre os acessos de $J$. curcas não estiveram relacionadas ao desempenho fotossintético, mas sim ao número de inflorescências e flores femininas, que são geneticamente determinadas. Além disso, a assimilação líquida de $\mathrm{CO}_{2}$ foi similar em ambos os genótipos, apesar de eles terem diferido na produção de frutos. Os genótipos diferiram consistentemente quanto à eficiência de carboxilação e à regeneração da ribulose bifosfato. Finalmente, o crescimento de ramo de $J$. curcas não é prejudicado pelo aumento no dreno durante a frutificação, e os frutos possivelmente estavam exercendo efeito positivo na assimilação líquida de $\mathrm{CO}_{2}$, o que pode ter permitido que as plantas mantivessem o crescimento ao produzir flores e frutos.
\end{abstract}

Termos para indexação: Jatropha curcas, biodiesel, eficiência de carboxilação, trocas gasosas, capacidade fotossintética.

\section{Introduction}

Physiological adaptations of Jatropha curcas have been recently studied in two regions of Brazil, with different climates: a semi-arid tropical climate, known as the Agreste; and a semi-humid tropical climate subjected to water stress (Santos et al., 2013). The study showed that the higher vapor pressure deficit of air during the dry season may induce stomatal closure, contributing to a reduction in the net photosynthetic rate. The authors also found that $J$. curcas displays dynamic photoinhibition, even in the dry season, and that plants only showed chronic photoinhibition under conditions of severe water deficit.

Jatropha curcas has not yet been studied in the Brazilian cerrado (savannah-like vegetation), which represents the major agricultural area in Brazil and is a strong candidate for the future cultivation of this species (Durães et al., 2011). The cerrado has distinct environmental conditions, being characterized by long dry periods and acid soils. Moreover, the largest germplasm collection of $J$. curcas in the country is 
field-maintained in this region (Alves et al., 2013) by the Empresa Brasileira de Pesquisa Agropecuária (Embrapa). This collection effectively represents the currently adapted planting stock in the country and is an important resource for breeding studies or repository for vegetative propagation (Laviola et al., 2012; Bhering et al., 2013).

The challenging environmental conditions of the cerrado would be expected to affect the phenological development (e.g., flowering and fruiting) of J. curcas, which, in turn, could have a major impact on the plant's physiological parameters. Flowers and fruits are thought of as priority sinks in the competition for photoassimilates, gaining carbon allocation at the expense of vegetative growth (Chaves et al., 2012). Consequently, reduced shoot growth is commonly observed in many plant species during the flowering and fruiting periods. However, since J. curcas produces inflorescences in the terminal buds of the branches grown during the current year (Domiciano et al., 2014), the production of new inflorescences ultimately depends on the vegetative growth of the plants. Under these conditions, J. curcas can only obtain high fruitloads if it continues growing while, at the same time, reallocating newly produced photoassimilates (together with those that were previously stored in the stem and roots) to both shoot growth and fruit development. However, increased sink strength with a corresponding decrease in the leaf-to-fruit ratio (LFR) could be partially compensated by an increase in photosynthesis. This phenomenon has been reported in some woody species, such as apple (Gucci et al., 1995), mango (Urban \& Léchaudel, 2005), and peach (Li et al., 2007), though no current information is available for $J$. curcas.

The advancements in the scientific knowledge related to how physiological process are modulated in response to environmental conditions and plant development, gained in this study, can be applied immediately for the development of new practices management or, in the long run, for the selection of $J$. curcas physiologically adapted to the cerrado regions. This is the first known investigation of the physiological processes and photosynthetic performance of $J$. curcas during major phenological development under field conditions, and one of the few studies that has specifically investigated the regulation of photosynthesis in the species.
The objective of this work was to evaluate the physiological processes in contrasting Jatropha curcas genotypes during the flowering and fruiting stages.

\section{Materials and Methods}

The experiments were carried out using the $J$. curcas active germplasm collection maintained at the experimental station of Embrapa Cerrados, located at Planaltina, DF, Brazil $\left(15^{\circ} 35^{\prime} 30^{\prime \prime} \mathrm{S}, 47^{\circ} 42^{\prime} 30^{\prime \prime} \mathrm{W}\right.$, at an altitude of $1,007 \mathrm{~m}$ ). Information on climate, soil, and management practices can be found in Domiciano et al. (2014). For this study, two field-grown accessions phenotypically contrasting in toxicity and yield, were evaluated: CNPAE-102 (a high-yielding toxic genotype) and CNPAE-169 (a low-yielding nontoxic genotype). The experiment used a randomized block design with five replicates. Each plot consisted of five plants in a row.

Measurements of morphological traits were made during the flowering and initial fruit development stages (mid-November 2012 to mid-January 2013 corresponding to late spring through early summer). The following parameters were assessed at 7-10 day intervals on the two newest branches carrying an inflorescence: number of inflorescences per branch, number of male flowers per branch, number of female flowers per inflorescence and per branch, and number of green fruits per branch. Plant height (m), measured from the soil to the highest branch; and branch growth rate ( $\mathrm{mm}$ per day) were also measured. Selected branches were marked and measured on a daily basis to access branch growth.

The LI-6400XT infrared gas analyzer (Li-Cor Inc., Lincoln, NE, USA) was used to measure the light-saturated rate of net $\mathrm{CO}_{2}$ assimilation $(A)$, stomatal conductance $\left(g_{\mathrm{s}}\right)$, internal-to-ambient $\mathrm{CO}_{2}$ concentration ratio $\left(C_{\mathrm{i}} / C_{\mathrm{a}}\right)$, transpiration $(E)$, leaf temperature $\left(T_{1}\right)$, chamber temperature $\left(T_{\mathrm{c}}\right)$, and relative humidity in the chamber $(\mathrm{RH})$. The ratio of instantaneous water-use efficiency - WUE $(A / E)$ - and the intrinsic water-use efficiency - iWUE $(A$ / $g_{\mathrm{s}}$ ) - were calculated using the measured values of $A$, $E$, and $g_{s}$. Leaf-air vapor pressure deficit $\left(\mathrm{VPD}_{\text {leaf-air }}\right)$ was calculated as the difference between the saturated $\left(e_{\mathrm{s}}\right)$ and real $(e)$ air pressures, using measurements of $T_{1}$ and $\mathrm{RH}$ in the chamber. Measurements were carried out at environmental temperatures (24 to 
$\left.33^{\circ} \mathrm{C}\right)$, and $\mathrm{CO}_{2}$ concentrations ( $\left.\sim 380-390 \mathrm{ppm}\right)$ under saturating photosynthetic photon flux density - PPFD $\left(1,200 \mu \mathrm{mol} \mathrm{m}^{-2} \mathrm{~s}^{-1}\right)$.

During measurements, daily temperature ranged from 24 to $33^{\circ} \mathrm{C}$, and $T_{1}$ ranged from 28 to $33^{\circ} \mathrm{C}$. The air relative humidity was about $80 \%$. The evaluations were conducted on two fully expanded leaves (one from each branch used in the phenotypic evaluations) per plant of each accession between 9:00 and 11:00 a.m. The branches and leaves used for the first measurement were tagged to allow the measurements to be taken in the same structure. Gas exchange measurements were carried out concomitantly with morphological measurements during clear days, in order to assess the effect of flowering and fruit development on gas exchange parameters.

To further explore physiological differences between accessions during flowering/fruiting, the response of net photosynthesis $(A)$ to internal leaf $\mathrm{CO}_{2}$ concentration ( $\mathrm{A} / \mathrm{Ci}$ curve) was determined in midDecember 2012 (summer season). This measurement allows evaluating the carboxylation efficiency of ribulose bisphosphate (RuBP) carboxylase/oxygenase (Rubisco) ( $\left.V_{\text {cmax }}\right)$, RuBP regeneration, triose phosphate use, electron transport rate $(J)$ when $A$ is limited by RuBP regeneration, mesophyll conductance $\left(\mathrm{g}_{\mathrm{m}}\right)$, and mitochondrial respiration during the flowering/fruiting period. For that a PPFD of 1,200 $\mu \mathrm{mol} \mathrm{m} \mathrm{m}^{-2} \mathrm{~s}^{-1}$ was used. The measurements started at 400 $\mu \mathrm{mol} \mathrm{mol}{ }^{-1} \mathrm{CO}_{2}$. Once the steady state was reached, the $\mathrm{CO}_{2}$ concentration was gradually lowered to $50 \mu \mathrm{mol}$ $\mathrm{mol}^{-1}$, and then increased in a stepwise progression up to $1,200 \mu \mathrm{mol} \mathrm{mol}{ }^{-1}$. The $\mathrm{CO}_{2}$ was injected into the open-circulating gas stream of the photosynthesis system using an auto-controlled $\mathrm{CO}_{2}$ injector. Twelve to fifteen sequential measurements of net photosynthesis were taken for each $\mathrm{A} / \mathrm{Ci}$ curve. Net photosynthesis values were plotted against the respective internal leaf $\mathrm{CO}_{2}$ concentrations $(\mathrm{Ci})$ (Farquhar \& Sharkey, 1982; Sharkey et al., 2007).

General differences in morphological traits and gas exchange parameters between genotypes and during the evaluation periods were assessed using the analysis of variance (Anova), at 5\% probability, performed with the Statistica software (Tibco Software Inc., Palo Alto, CA, USA). The interaction effect between genotype and assessment period (days after flowering) was also tested by the Anova, at 5\% probability. A point-by-point comparison between the genotypes was performed using Student's t-test, to compare the genotypes in each evaluation time. These analyzes were computed using SAS (SAS Institute Inc., Cary, NC, USA).

\section{Results and Discussion}

The two studied genotypes differed for most of the morphological traits that were evaluated (Figure 1). Even though a difference in number of inflorescences on the labeled branches could not be found, a significant difference in number of female and male flowers was detected after the appearance of the first inflorescences, which occurred in mid-November 2012. Consequently, both genotypes also differed in number of green fruits on the labeled branches. It should be noted that CNPAE-102 is taller than CNPAE-169 (Figure 1).

As anticipated, differences were observed for all of the evaluated traits, except for growth rate. All together, the gathered data indicates that Jatropha keeps a steady rate of branch growth (in average 51.54 $\mathrm{mm}$ per day), even during flowering and fruiting and despite the fact that flowers and fruits are considered primary sinks for photoassimilates.

Most of the differences between genotypes, with the exception of height and number of green fruits per labeled branch, are more pronounced from the beginning of flowering until 35 days after bloom. Differences between genotypes were consistently observed at this period (Figure 1). In the case of height and number of green fruits per labeled branch, CNPAE-102 tended to be taller and produce more fruits by the end of the evaluation period.

Overall, the genotypes did not differ for most of the assessed gas exchange parameters, with the exception of $g s$ and $A / g_{s}$, for which differences were detected (Figures 2 and 3). Interestingly, $A$ for both accessions is equivalent (on average $17.70 \mu \mathrm{mol} \mathrm{m} \mathrm{m}^{-2} \mathrm{~s}^{-1}$ ), although both genotypes differ regarding gs (CNPAE-102 has greater $g_{s}$ than CNPAE-169). This fact, together with similar values for $C_{i} / C_{a}$, indicated the need to investigate possible differences in the carboxylation efficiency of Rubisco, RuBP regeneration, triose phosphate, and $\mathrm{g}_{\mathrm{m}}$ between genotypes (DaMatta et al., 2008). It was hypothesized that the net $\mathrm{CO}_{2}$ assimilation rate $(A)$ was equal in both genotypes because they 
are not equally efficient at fixing $\mathrm{CO}_{2}$. To test this hypothesis, the response of the net photosynthesis $(A)$ of both genotypes to internal leaf $\mathrm{CO}_{2}$ concentration ( $\mathrm{A} / \mathrm{Ci}$ curve) in mid-December 2012 was analyzed. The maximum rate of ribulose 1,5-bisphosphate
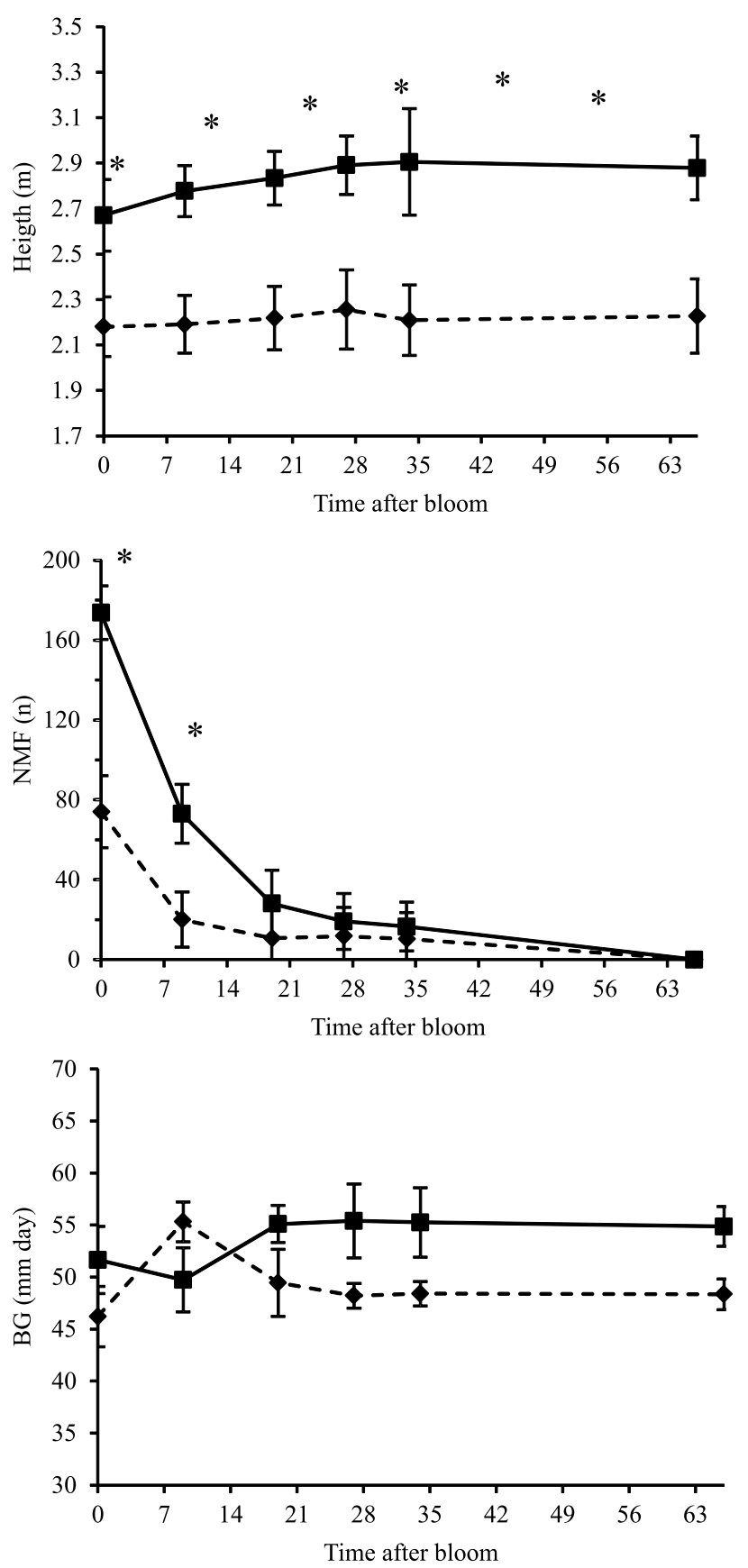

(RuBP) carboxylation $\left(V_{\text {cmax }}\right)$ is indeed higher in the accession with lower gs (CNPAE-169) (Figure 4). The $g_{\mathrm{m}}$ of CNPAE-169 is higher than that in CNPAE-102. Despite both genotypes showing different $g s$, their $E$ was similar. This probably indicates that the genotypes
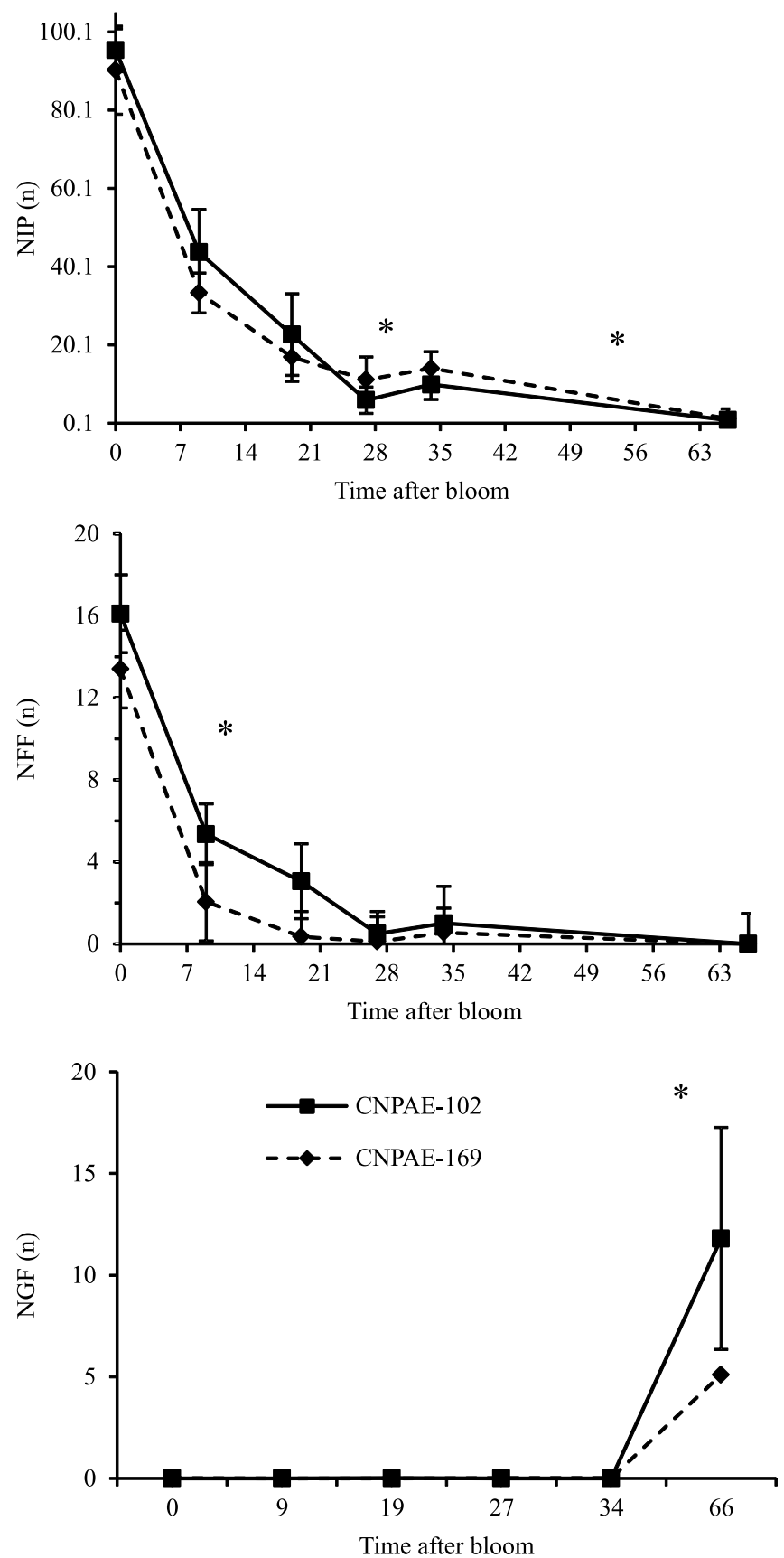

Figure 1. Morphological traits evaluated: A, height, B, number of inflorescences per plant (NIP); C, number of male flowers per plant (NMF); D, number of female flowers per plant (NFF); E, growth rate (GR); and F, number of green fruits (NGF) of two contrasting Jatropha curcas accessions (CNPAE-102 and CNPAE-169). Bars represent the standard deviation, and asterisks indicate significant differences between the means, in each evaluation time, according to the t-test, at 5\% probability. 
have different water-use efficiency, confirming the significant differences for intrinsic water-use efficiency $\left(A / g_{\mathrm{s}}\right)$. However, no differences were recorded for instantaneous water-use efficiency $(A / E)$.

Differences were found for all of the evaluated gas exchange parameters during the studied period (Figures 2 and 3). Therefore, the data was plotted on bi-dimensional graphs to allow a point-by-point comparison to be performed in order to explore the significance of the effect (Figure 2). In that respect, $A$ tends to decrease at the beginning of the flowering period, to then stabilize once the fruits are starting to develop (Figures $1 \mathrm{~F}$ and $2 \mathrm{~A}$ ). This may be due to the increase in the $\mathrm{VPD}_{\text {leaf-air }}$ in mid-December 2012, as $g s$ is often diminished under such conditions (Figure $3 \mathrm{C}$ ). An inverse trend was observed for $C_{i} / C_{a}$, as changes in this ratio inversely tracked those of $A$ (Figure $2 \mathrm{~A}$ and $\mathrm{C}$ ).

Overall, the shapes of the plotted data were similar in both genotypes (Figure 2). This possibly indicates that the control of gas exchange through stomata aperture control is similar in both accessions in relation to environmental conditions (DaMatta et al., 2008). Consistently, no significant interaction between accessions and evaluation period was detected for $g s$, even though such interactions were observable for other parameters such as $A$ (Figure $2 \mathrm{~B}$ ). For this parameter, it can be noted that genotype CNPAE-102 had higher photosynthetic performance when compared with CNPAE-169 at the beginning of the flowering period. However, at the beginning of the fruiting stage, genotype CNPAE-169 tended to assimilate more $\mathrm{CO}_{2}$ than CNPAE-102 (Figure 2). This inversion denotes the occurrence of a simple interaction between accessions and evaluation period. $E$ varied during this period, closely tracking the changes in $g s$ and $A$. Changes in the mesophyll capacity to fix $\mathrm{CO}_{2}$ are probably related to this behavior since both internal $\left(C_{\mathrm{i}}\right)$ and environmental $\mathrm{CO}_{2}$ concentration $\left(C_{\mathrm{a}}\right)$ did not differ.

There was no significant correlation between $A$ and $C_{\mathrm{i}} / C_{\mathrm{a}}$ during the flowering/fruiting period (Table 1 ), further supporting the hypothesis that changes in photosynthesis are related to the mesophyll capacity to fix $\mathrm{CO}_{2}$. A significant correlation between $A$ and $g s$ was only detected for CNPAE-169. In CNPAE-102, gs showed little variation during the evaluation period (Figure 2 B). There was a negative correlation between $A$ and the $\mathrm{VPD}_{\text {leaf-air }}$ in CNPAE-169. Indeed, the decline in $A$ (Figure $2 \mathrm{~A}$ ) may be directly related to the increase in $\mathrm{VPD}_{\text {leaf-air }}$ (Figure $3 \mathrm{C}$ ). However, this deficit and $g s$ were not correlated. This is intriguing, since increasing $\mathrm{VPD}_{\text {leaf-air }}$ is thought to cause stomata to close as an adaptation to conserve water (Kawamitsu et al., 1993). Finally, as anticipated, a strong positive correlation between $A$ and $E$ was found (Table 1).

A significant positive correlation between $A$ and the number of inflorescences and number of male and female flowers was detected in CNPAE-102 (Table 2). Although the number of inflorescences and flowers tracked $A$ (Figures 1 and 2), it is unlikely that there is a cause-effect relationship because of the moderate negative correlation that occurred between $A$ and the number of green fruits on labeled branches for this same genotype (Table 2). Previous studies (Domiciano et al., 2014) showed that the number of green fruits and the number of inflorescences and flowers are genuinely correlated, suggesting the correlation between flower traits and $A$ is spurious.

The negative correlation between $A$ and the number of green fruits occurred because the number of green fruits increases in the mid-to-latter part of the evaluations, while $A$ decreases in the mid-to-latter part of the evaluations due to higher $V_{P D} D_{\text {leaf-air. }}$ The stabilization of $A$ at the end of the experiment was not enough to change this correlation. However, as fruits are primary sinks, the increase in the number of green fruits at the end of the experiment may be related to the observed stabilization in $A$.

Most studies on the physiological aspects of Jatropha cultivation have concentrated on nutritional aspects, salinity, drought, and cold stress (Zheng et al., 2009; Aragão et al., 2012; Díaz-López et al., 2012; Silva et al., 2013). To the best of our knowledge, this is the first investigation of the physiological processes and photosynthetic performance of Jatropha during major phenological development under field conditions, and one of the few studies that has specifically investigated regulation of photosynthesis in Jatropha (Aragão et al., 2012; Silva et al., 2012).

Genotype CNPAE-102 produces on average $130 \%$ more green fruits than genotype CNPAE-169 (Domiciano et al., 2014). However, the data of this study also indicates that $A$ in both genotypes is broadly equivalent under field conditions, assuming that the number of green fruits in the labeled branches can be considered as a yield indicator (Laviola et al., 2012) 
and that CNPAE-102 has been previously shown to be more productive than CNPAE-169. A plausible explanation is that the difference in yield is not due to the photosynthetic potential but to the major role played by yield components. If the number of green fruits that develop in a given genotype was dependent on its photosynthetic performance (Gibson et al., 2011), it would be expected that the more productive genotype be characterized by an enhanced photosynthetic performance allowing more photoassimilates to be reallocated to the developing fruits. However, a significant difference in the number of female and male flowers between genotypes was detected. These traits are highly heritable - broad-sense heritabilities have been estimated at $42 \%$ on average by Mohapatra \& Panda (2010) -, and, in a given crop year, neither the number of inflorescences and female flowers differed significantly between genotypes, and the number of
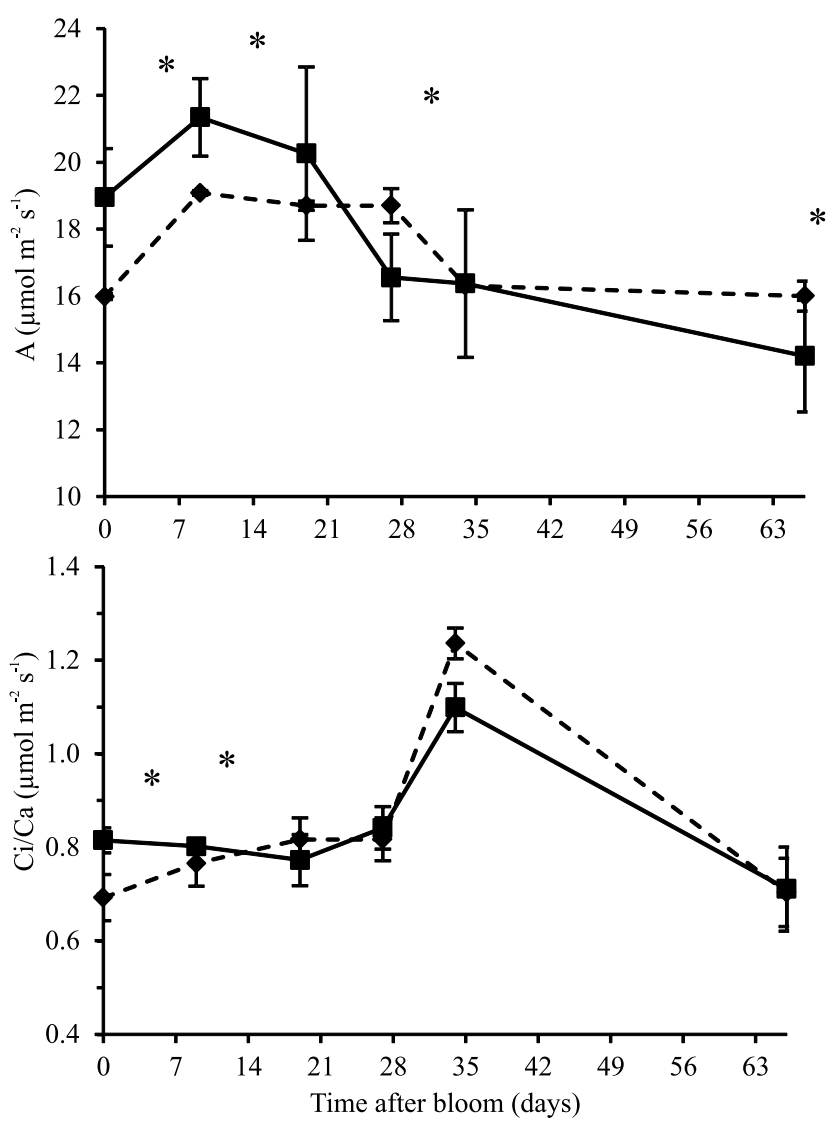

green fruits is quite similar regardless of the genotype being analyzed. This suggests that, rather than being dependent on the photosynthetic performance of the genotypes, yield in $J$. curcas is primarily affected by the number of inflorescences and the number of female flowers. Therefore, breeding for more productive genotypes should focus on the selection of genotypes with favorable ratio of male to female flowers, rather than on photosynthetically efficient genotypes.

CNPAE-102 and CNPAE-169 appear to have nearly identical photosynthetic performances, given that both are assimilating $\mathrm{CO}_{2}$ at a similar rate. However, the data of this works also poses evidences that these genotypes differ in terms of stomatal function. Differences in stomatal aperture (measured through $g s)$ are expected to impact the amount of $\mathrm{CO}_{2}$ available for photosynthesis and, consequently, similar values of $A$ are likely caused by differences in the assimilation
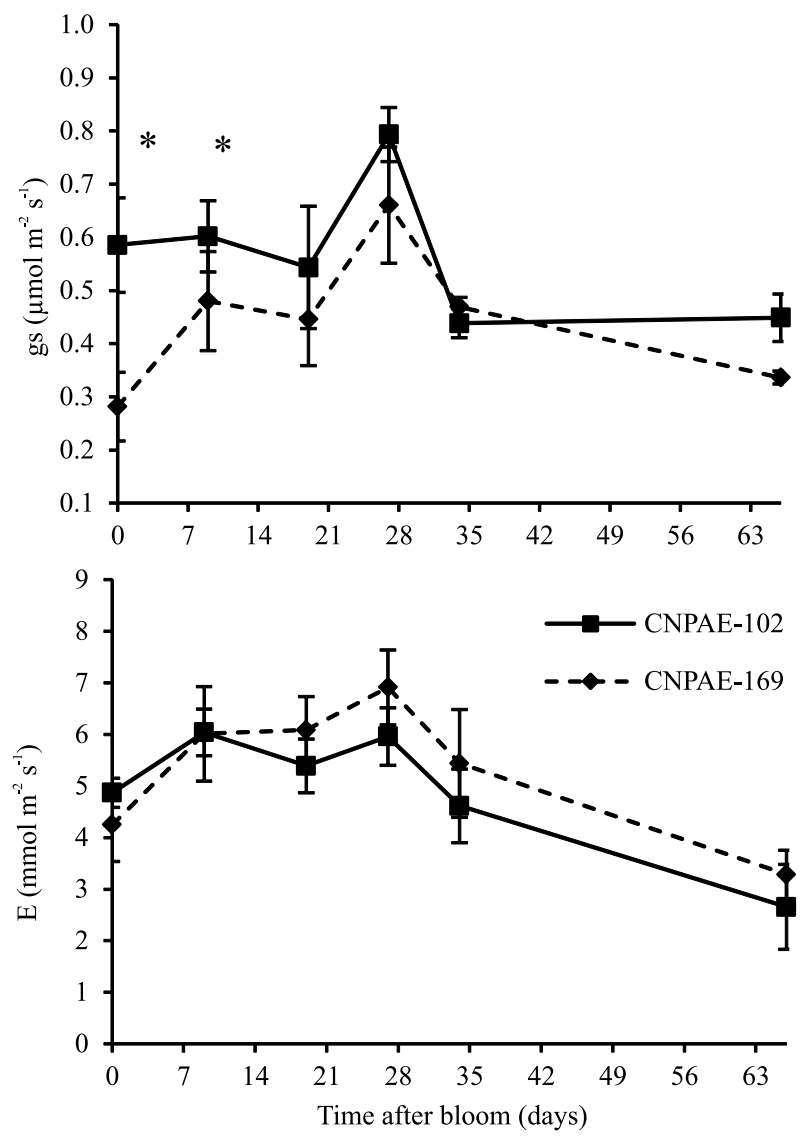

Figure 2. Evaluated parameters: $\mathrm{A}$, net carbon assimilation rate $(A)$; B, stomatal conductance to water vapor $\left(g_{\mathrm{s}}\right)$; C, internalto-ambient $\mathrm{CO}_{2}$ concentration ratio $\left(C_{\mathrm{i}} / C_{\mathrm{a}}\right)$; and $\mathrm{D}$, transpiration rate $(E)$ of two contrasting Jatropha curcas accessions (CNPAE-102 and CNPAE-169). Bars represent the standard deviation, and asterisks indicate significant differences between the means, in each evaluation time, according to the t-test, at $5 \%$ probability. 
of atmospheric $\mathrm{CO}_{2}$ (Alves et al., 2011). However, this does not seem to be the case here. Ultimately, such assimilation depends on differences in the capacity of the biochemical reactions that regulate the gasexchange process (Wullschleger, 1993; DaMatta et al.,
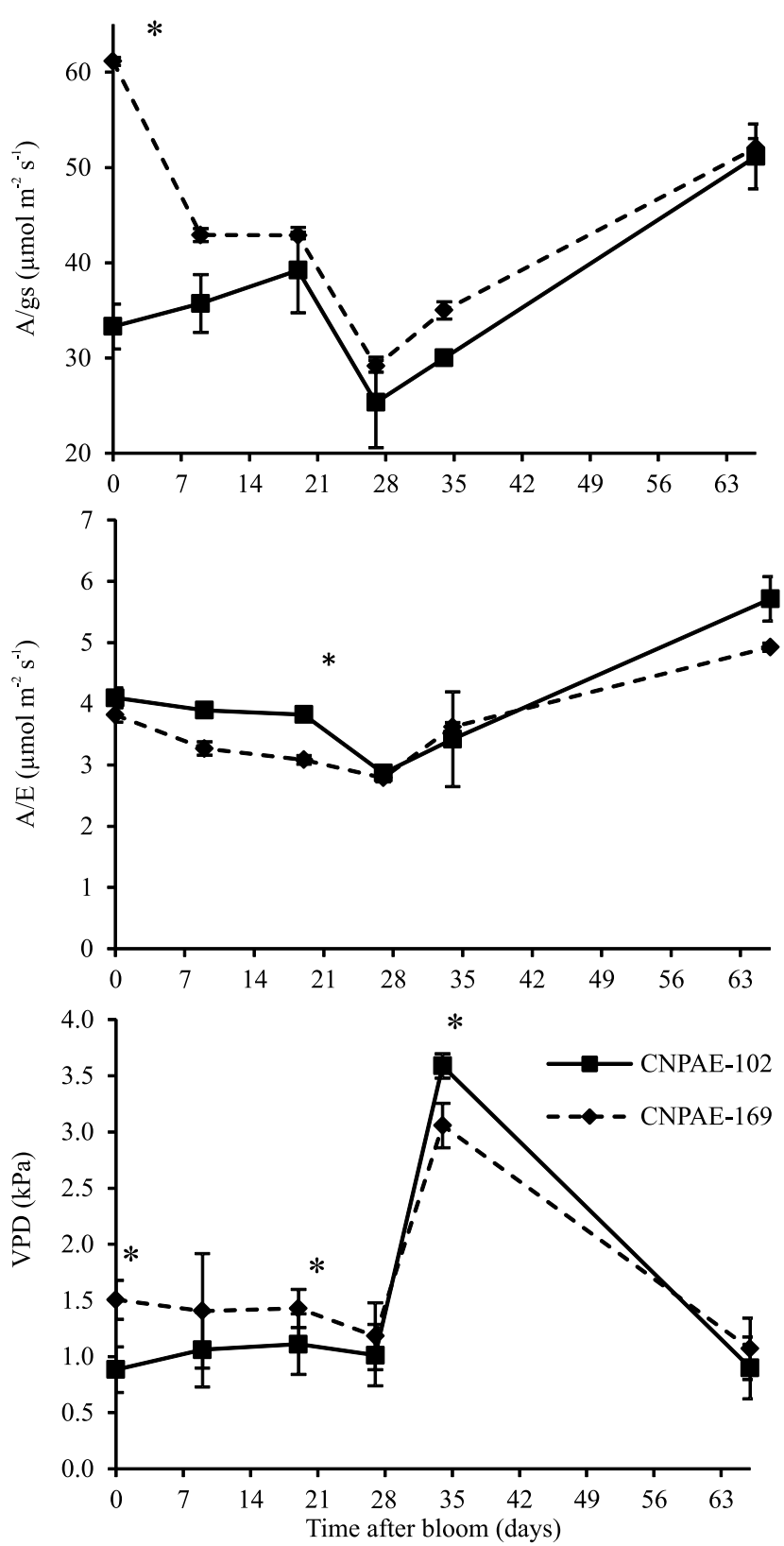

Figure 3. Evaluated parameters: A, intrinsic water-use efficiency $\left(A / g_{\mathrm{s}}\right)$; B, water-use efficiency $(A / E)$; and $\mathrm{C}$, vapor deficit pressure (VPD) of two contrasting Jatropha curcas accessions (CNPAE-102 and CNPAE-169). Bars represent the standard deviation and asterisks indicate significant differences between the means, in each evaluation time, according to the t-test, at $5 \%$ probability.
2016). Therefore, genotypic differences in terms of the carboxylation efficiency or photochemical efficiency of photosystem II may exist between CNPAE-102 and CNPAE-169. Indeed, significant differences were detected for the maximum capacity for Rubisco catalyzed carboxylation of RuBP $\left(V_{\text {cmax }}\right)$ and for the maximum rate of photosynthetic electron transport $(J)$. All these parameters are higher in the accession with the lowest gs (CNPAE-169) (Table 1). These parameters have been shown to accurately describe plant photosynthetic capacity at the leaf level in $\mathrm{C}_{3}$ plants (Fan et al., 2011), and the correlation between these parameters and photosynthetic capacity has been the subject of extensive research in a wide variety of plants (Farquhar \& Sharkey 1982; Sharkey et al., 2007). Therefore, even though the amount of $\mathrm{CO}_{2}$ available for photosynthesis may be smaller, certain genotypes may be able to use it more efficiently. In any case, the finding that the $g_{\mathrm{m}}$ of CNPAE-169 is also higher (Table 3 and Figure 4) may also help explain the similar $A$ values, as lower $g s$ may be partially compensated by increased $g_{\mathrm{m}}$.

The data here presented evidence that $A$ is reduced after the beginning of the flowering period. This same trend has been reported before in other plant species such as mango (Urban et al., 2008). Many factors may be causing this effect, but the obtained data suggests that the rise in $\mathrm{VPD}_{\text {leaf-air }}$ may have contributed to the decrease in $A$ - at least for genotype CNPAE-169. In such a situation, $g s$ is often reduced due to stomata remaining closed for longer periods

Table 1. Estimates for the maximum velocity of Rubisco for carboxylation $\left(V_{\text {cmax }}\right)$, electron transport rate when $A$ is limited by ribulose bisphosphate regeneration $(J)$, respiratory $\mathrm{CO}_{2}$ release rather than by photorespiration $\left(R_{\mathrm{d}}\right)$, and mesophyll conductance $\left(g_{\mathrm{m}}\right)$ based on $A / C_{\mathrm{i}}$ curves for two Jatropha curcas genotypes (CNPAE-102 and CNPAE-169) during the flowering/fruiting period.

\begin{tabular}{|c|c|c|c|c|c|}
\hline \multirow{3}{*}{$\begin{array}{l}A / C_{\mathrm{i}} \\
\text { parameter }\end{array}$} & \multicolumn{4}{|c|}{ Accession/temperature ${ }^{(1)}$} & \multirow[t]{3}{*}{ Unit } \\
\hline & \multicolumn{2}{|c|}{ CNPAE-102 } & \multicolumn{2}{|c|}{ CNPAE-169 } & \\
\hline & LT & RT & LT & RT & \\
\hline$V_{\text {cmax }}$ & 194 & 194 & 285 & 285 & $\mu \mathrm{mol} \mathrm{m} \mathrm{m}^{-2} \mathrm{~s}^{-1}$ \\
\hline$J$ & 218 & 218 & 380 & 380 & $\mu \mathrm{mol} \mathrm{m} \mathrm{m}^{-2} \mathrm{~s}^{-1}$ \\
\hline TPU & 14.7 & 14.7 & 26.8 & 26.9 & $\mu \mathrm{mol} \mathrm{m} \mathrm{m}^{-2} \mathrm{~s}^{-1}$ \\
\hline$R_{\mathrm{d}}$ & 12.07 & 12.06 & 36.61 & 36.59 & $\mu \mathrm{mol} \mathrm{m} \mathrm{m}^{-2} \mathrm{~s}^{-1}$ \\
\hline$g_{\mathrm{m}}$ & 0.98 & 0.98 & 1.40 & 1.40 & $\mu \mathrm{mol} \mathrm{m}{ }^{-2} \mathrm{~s}^{-1} \mathrm{~Pa}^{-1}$ \\
\hline
\end{tabular}

(1) $\mathrm{LT}$, leaf temperature; and RT, for room temperature $\left(25^{\circ} \mathrm{C}\right)$. 
in order to conserve the water status of the plants (Kawamitsu et al., 1993). However, no significant correlation between $g s$ and $\mathrm{VPD}_{\text {leaf-air }}$ was found for either genotype. This contrasts with Rajaona et al. (2013), who reported a strong correlation between those two variables when $\mathrm{VPD}_{\text {leaf-air }}$ ranged from 1.5 to $6 \mathrm{kPa}$. Given the lack of association between $\mathrm{VPD}_{\text {leaf-air }}$ and $g_{s}$ in the experiment, one hypothesis is that the increase in $\mathrm{VPD}_{\text {leaf-air }}$ is only partially responsible for the observed decrease in photosynthesis during the flowering period.
The data also suggests that the limitation of $A$ during the flowering period does not seem to be related to diffusive factors, as observed for some other species (Batista et al. 2012). In defruited coffee plants, for example, decreased $A$ is largely a consequence of lower $\mathrm{CO}_{2}$ availability for photosynthesis coupled to lower $g s$ (DaMatta et al., 2008). However, there is no consistent decrease in $A$ with decreased gs (Table 3). Since it has been shown that $A$ may be depressed by direct feedback, and that photosynthesis and the activities of related biosynthetic enzymes also decrease as end products

Table 2. Pearson correlation coefficient among gas exchange parameters measured under naturally fluctuating environmental conditions in two selected Jatropha curcas genotypes (CNPAE-102 and CNPAE-169) during the flowering/fruiting period ${ }^{(1)}$.

\begin{tabular}{|c|c|c|c|c|c|c|c|}
\hline \multirow[t]{2}{*}{ Parameter $^{(2)}$} & \multicolumn{7}{|c|}{ Gas exchange parameter } \\
\hline & $A$ & $g \mathrm{~s}$ & $E$ & $C_{\mathrm{i}} / C_{\mathrm{a}}$ & $A / g_{\mathrm{s}}$ & $A / E$ & $V P D$ \\
\hline $\bar{A}$ & 1 & $0.1482^{\text {ns }}$ & $0.5334 * *$ & $-0.1381^{\mathrm{ns}}$ & $0.0141^{\mathrm{ns}}$ & $-0.2570 *$ & $-0.1861^{\mathrm{ns}}$ \\
\hline$g_{\mathrm{s}}$ & $0.6102 * *$ & 1 & $0.4349 * *$ & $0.0928^{\text {ns }}$ & $-0.4030 * *$ & $-0.2709 * *$ & $-0.3025^{\mathrm{ns}}$ \\
\hline$E$ & $0.5616^{* *}$ & $0.6826 * *$ & 1 & $0.1074^{\mathrm{ns}}$ & $-0.3165^{*}$ & $-0.1993^{\mathrm{ns}}$ & $0.0075^{\mathrm{ns}}$ \\
\hline$C_{\mathrm{i}} / C_{\mathrm{a}}$ & $-0.0486^{\mathrm{ns}}$ & $0.2067^{\mathrm{ns}}$ & $0.299^{\mathrm{ns}}$ & 1 & $-0.8560 * *$ & $0.8393 * *$ & $0.7393 * *$ \\
\hline$A / g_{\mathrm{s}}$ & $-0.1187^{\mathrm{ns}}$ & $-0.5933 * *$ & $-0.33976 * *$ & $-0.8297 * *$ & 1 & $-0.6470 * *$ & $-0.6213 * *$ \\
\hline$A / E$ & $-0.2628^{*}$ & $-0.0289^{\mathrm{ns}}$ & $-0.0630^{\mathrm{ns}}$ & $0.8999 * *$ & $-0.7353 * *$ & 1 & $0.939 * *$ \\
\hline$V P D$ & $-0.3306^{* *}$ & $-0.1733^{\mathrm{ns}}$ & $0.0585^{\text {ns }}$ & $0.6823^{* *}$ & $-0.5491 * *$ & $0.8616^{* *}$ & 1 \\
\hline
\end{tabular}

${ }^{(1)}$ Correlations for CNPAE-102 are shown above the diagonal, whereas the correlations for CNPAE-169 are shown below the diagonal. ${ }^{(2)} \mathrm{A}$, net carbon assimilation rate; $\mathrm{g}_{\mathrm{s}}$, stomatal conductance to water vapor; $\mathrm{E}$, transpiration rate; $\mathrm{C}_{\mathrm{i}} / \mathrm{C}_{\mathrm{a}}$, internal to ambient $\mathrm{CO}_{2}$ concentration ratio; $\mathrm{A} / \mathrm{gs}$, the intrinsic water-use efficiency; A/E, the ratio of instantaneous water-use efficiency; and VPD, vapor pressure deficit. ${ }^{n}$ Nonsignificant difference. ${ }^{* *}$ and*Significant differences by the t-test, at 1 and $5 \%$ probability, respectively.

Table 3. Pearson correlation coefficient among gas exchange parameters and morpho-agronomic traits measured under naturally fluctuating environmental conditions in the CNPAE-102 and CNPAE-169 Jatropha curcas accession during the flowering/fruiting period.

\begin{tabular}{|c|c|c|c|c|c|c|c|}
\hline \multirow[t]{2}{*}{ Morpho-agronomic trait ${ }^{(1)}$} & \multicolumn{7}{|c|}{ Gas exchange parameter ${ }^{(2)}$} \\
\hline & $A$ & $g \mathrm{~s}$ & $E$ & $C_{\mathrm{i}} / C_{\mathrm{a}}$ & $A / g_{\mathrm{s}}$ & $A / E$ & $V P D$ \\
\hline & \multicolumn{7}{|c|}{ CNPAE-102 } \\
\hline Height & $-0.1598^{\mathrm{ns}}$ & $-0.0314^{\mathrm{ns}}$ & $-0.3984 * *$ & $0.0961^{\mathrm{ns}}$ & $0.0126^{\mathrm{ns}}$ & $0.1414^{\mathrm{ns}}$ & $-0.0234^{\mathrm{ns}}$ \\
\hline NIP & $0.3064^{*}$ & $0.0812^{\mathrm{ns}}$ & $0.0688^{\mathrm{ns}}$ & $-0.0532^{\mathrm{ns}}$ & $0.0098^{\mathrm{ns}}$ & $-0.2176^{\mathrm{ns}}$ & $-0.2752 *$ \\
\hline NMF & $0.3361 * *$ & $0.0223^{\mathrm{ns}}$ & $0.1035^{\mathrm{ns}}$ & $-0.0716^{\mathrm{ns}}$ & $0.0574^{\mathrm{ns}}$ & $-0.2082^{\text {ns }}$ & $-0.2404^{\text {ns }}$ \\
\hline NFF & $0.2770^{*}$ & $0.0573^{\mathrm{ns}}$ & $0.0445^{\mathrm{ns}}$ & $-0.0661^{\mathrm{ns}}$ & $0.06353^{\mathrm{ns}}$ & $-0.2174^{\mathrm{ns}}$ & $-0.2697^{*}$ \\
\hline BG & $-0.0846^{\mathrm{ns}}$ & $0.0248^{\mathrm{ns}}$ & $-0.3199 *$ & $-0.0487^{\mathrm{ns}}$ & $-0.0237^{\mathrm{ns}}$ & $0.0475^{\mathrm{ns}}$ & $-0.0463^{\text {ns }}$ \\
\hline \multirow[t]{2}{*}{ NGF } & $-0.5030 * *$ & $-0.1952^{\mathrm{ns}}$ & $-0.6092 * *$ & $-0.3945 * *$ & $0.4802 * *$ & $-0.1171^{\mathrm{ns}}$ & $-0.2091^{\mathrm{ns}}$ \\
\hline & \multicolumn{7}{|c|}{ CNPAE-169 } \\
\hline Height & $0.0074^{\mathrm{ns}}$ & $0.1176^{\mathrm{ns}}$ & $0.2517^{*}$ & $-0.0414^{\mathrm{ns}}$ & $-0.0520^{\mathrm{ns}}$ & $-0.0595^{\mathrm{ns}}$ & $0.0141^{\mathrm{ns}}$ \\
\hline NIP & $-0.1063^{\mathrm{ns}}$ & $-0.3223^{*}$ & $-0.2128^{\mathrm{ns}}$ & $-0.2590 *$ & $0.4077 * *$ & $-0.1898^{\text {ns }}$ & $-0.0870^{\text {ns }}$ \\
\hline NFM & $-0.1824^{\mathrm{ns}}$ & $-0.2983^{*}$ & $-0.2144^{\mathrm{ns}}$ & $-0.2219^{\text {ns }}$ & $0.3257 *$ & $-0.1569^{\mathrm{ns}}$ & $-0.0859^{\text {ns }}$ \\
\hline NFF & $-0.1140^{\text {ns }}$ & $-0.2942 *$ & $-0.2148^{\mathrm{ns}}$ & $-0.2279^{\mathrm{ns}}$ & $0.3423 * *$ & $-0.1491^{\mathrm{ns}}$ & $-0.0815^{\mathrm{ns}}$ \\
\hline BG & $-0.0613^{\mathrm{ns}}$ & $0.0088^{\mathrm{ns}}$ & $-0.0810^{\mathrm{ns}}$ & $-0.0444^{\mathrm{ns}}$ & $0.0255^{\mathrm{ns}}$ & $-0.0715^{\text {ns }}$ & $-0.0124^{\mathrm{ns}}$ \\
\hline NGF & $-0.3396^{* *}$ & $-0.2891^{*}$ & $-0.5544 * *$ & $-0.2456^{\mathrm{ns}}$ & $0.2561 *$ & $-0.1223^{\text {ns }}$ & $-0.2664 *$ \\
\hline
\end{tabular}


accumulate under decreasing source demand (Paul \& Foyer 2001), the hypothesis at the present study is that the reduction in $A$ during the flowering period is related to the feedback inhibition of photosynthesis by its end products.

The pivotal effect of sink activity on photosynthesis and carbon partitioning has been well documented in several species, including trees such as mango (Urban et al., 2004) and peach (Li et al., 2007). Under conditions of decreased sink demand (which are likely to occur during $J$. curcas flowering), end-product accumulation in source leaves may restrict net photosynthetic rate (DaMatta et al., 2008). Excessive accumulation of starch may impair chloroplast function, limiting photosynthesis directly through mechanisms such as restriction of $\mathrm{CO}_{2}$ diffusion or rupturing of chloroplasts (Paul \& Foyer , 2001). Robust correlations between high starch content in leaves and low assimilation rates have also been reported (Paul \& Foyer 2001). Various factors could provide feedback signals related to the retardation of inorganic phosphate (Pi) recycling (Gibson et al., 2011), including: changes in the amount or timing of glucose production from starch and its export from the chloroplast under situations of high starch accumulation (Paul \& Foyer, 2001); limitations on the capacity for sucrose and starch synthesis; or conditions where the

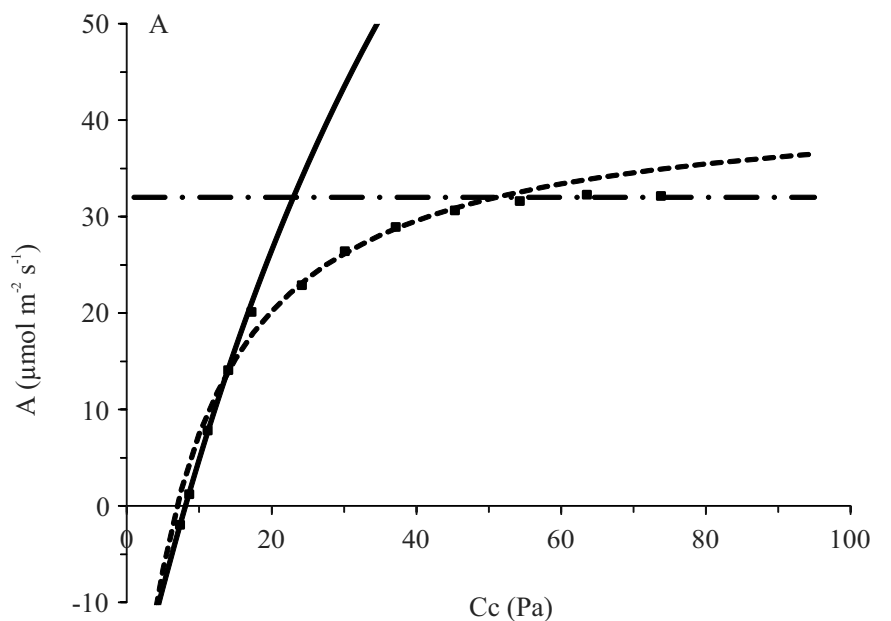

potential for photosynthesis exceeds the rate of endproduct synthesis.

One final conclusion can be drawn: J. curcas branch growth is not impaired due to the increased sink strength from fruiting. This is interesting as flowers and fruits may act as priority sinks, and, during the flowering and fruiting periods, a strong limitation on shoot growth has been observed in many perennial plant species (Chaves et al., 2012). This response has traditionally been attributed to the exhaustion of stored carbohydrates and minerals - during flowering and fruiting, the allocation of photoassimilates to such organs may surpass the allocation of carbon to branch growth (Chaves et al., 2012). In this species, however, the increased sink strength from fruiting does not seem to affect branch growth, which remained virtually unchanged during this period. Jatropha curcas are deciduous (Durães et al., 2011), losing all their leaves in the dry season. The resumption of growth by the emergence of new branches and later inflorescences starts with the rainy season (Domiciano et al., 2014). Due to the previous loss of leaves, plants need to survive this period by using water and organic reserves, mainly sucrose and starch (Gupta \& Kaur, 2000), stored in stems and roots during the previous phenological cycle.

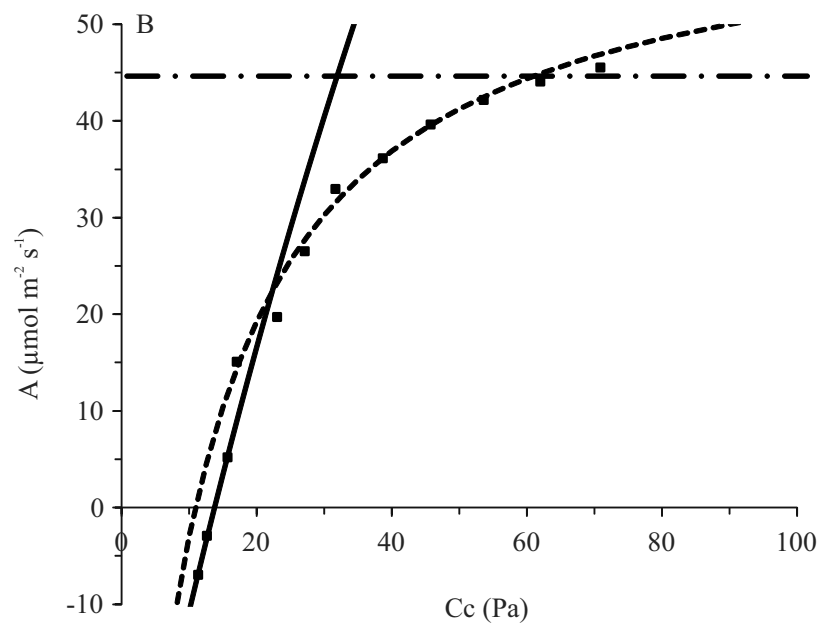

- Aobs — Rubisco -.--.- RuBP_regen -.-.-TPU

Figure 4. Response of net photosynthesis to internal leaf $\mathrm{CO}_{2}$ concentration $\left(A / C_{\mathrm{i}}\right.$ curves $)$ for two contrasting Jatropha curcas accessions: A, CNPAE-102; and B, CNPAE-169 during the flowering/fruiting period. Squares represent the actual measured data. Carboxylase/oxygenase (Rubisco)-limited photosynthesis stage is shown in full line, while ribulose bisphosphate (RuBP)-regeneration-limited photosynthesis stage (where A is limited by the regeneration rate of RuBP) is shown in dotted lines. Triose phosphate use (TPU) limitation stage is shown in slashed/dotted line.

Pesq. agropec. bras., Brasília, v.53, n.1, p.10-21, Jan. 2018

DOI: 10.1590/S0100-204X2018000100002 
The emission of the new leaves is also dependent on the reallocation of photoassimilates and nutrients stored in the stems and roots (Laviola \& Dias, 2008). Until the young leaves make the transition from a weak sink to a strong source (which happens during expansion), the stored starch and sucrose need to be efficiently used to support continuous growth. Seasonal variation in starch concentrations have been found in stems and branches of deciduous trees, and sucrose and starch concentrations have been observed to be dramatically reduced during the reestablishment period (Gupta \& Kaur, 2000). Based on this, the maintenance of growth may be related to the reallocation of the photoassimilates previously stored. Other possibilities are that fruits may be exerting a positive effect on the rate of leaf net $\mathrm{CO}_{2}$ assimilation $(A)$ and also efficiently assimilating part of the carbon used in their own development (Ranjan et al., 2012).

An increased rate of photosynthesis that compensates for a decreased LFR has been reported in some woody species such as apple (Gucci et al., 1995), mango (Urban \& Léchaudel, 2005), and peach (Li et al., 2007). This study, presents the first evidence that this can also happen in $J$. curcas during the flowering and fruiting periods. This is important, since such compensation and the production of a larger amount of fruits by the plants is not common in many other perennials crops, only in olive (Proietti, 2000) and oil palm (Legros et al., 2009). In $J$. curcas, such compensation is probably a physiological mechanism to ensure a high fruit load. It must be stressed that this species produces inflorescences in the terminal buds of branches grown during the current year, and, therefore, it needs continuous and steady growth to produce a large amount of fruits.

\section{Conclusions}

1. The differences in yield between Jatropha curcas accessions are not related to photosynthetic capacity, but rather to the number of inflorescences and female flowers.

2. Although both $J$. curcas genotypes have equivalent $\mathrm{CO}_{2}$ assimilation, they differ as to carboxylation efficiency and ribulose bisphosphate (RuBP) regeneration.

3. Reductions in net $\mathrm{CO}_{2}$ assimilation during the flowering period may be related to higher leaf-air vapor pressure deficits and feedback inhibition.

\section{Acknowledgments}

To Ministério da Ciência, Tecnologia, Inovações e Comunicações (MCTI) and Empresa Pública de Fomento à Ciência, Tecnologia e Inovação (Finep), for financial support (project BRJatropha); to MKTPlace Initiative, for research grant.

\section{References}

ALVES, A.A.; BHERING, L.L.; ROSADO, T.B.; LAVIOLA, B.G.; FORMIGHIERI, E.F.; CRUZ, C.D. Joint analysis of phenotypic and molecular diversity provides new insights on the genetic variability of the Brazilian physic nut germplasm bank. Genetics and Molecular Biology, v.36, p.371-381, 2013. DOI: 10.1590/S1415-47572013005000033.

ALVES, A.A.; GUIMARÃES, L.M. da S.; CHAVES, A.R. de M.; DAMATTA, F.M.; ALFENAS, A.C. Leaf gas exchange and chlorophyll a fluorescence of Eucalyptus urophylla in response to Puccinia psidii infection. Acta Physiologiae Plantarum, v.33, p.1831-1839, 2011. DOI: 10.1007/s11738-011-0722-z.

ARAGÃO, R.M.; SILVA, E.N.; VIEIRA, C.F.; SILVEIRA, J.A.G. High supply of $\mathrm{NO}_{3}{ }^{-}$mitigates salinity effects through an enhancement in the efficiency of photosystem II and $\mathrm{CO}_{2}$ assimilation in Jatropha curcas plants. Acta Physiologiae Plantarum, v.34, p.2135-2143, 2012. DOI: 10.1007/s11738-0121014-y.

BATISTA, K.D.; ARAÚJO, W.L.; ANTUNES, W.C.; CAVATTE, P.C.; MORAES, G.A.B.K.; MARTINS, S.C.V.; DAMATTA, F.M. Photosynthetic limitations in coffee plants are chiefly governed by diffusive factors. Trees, v.26, p.459-468, 2012. DOI: 10.1007/s00468011-0606-2.

BHERING, L.L.; BARRERA, C.F.; ORTEGA, D.; LAVIOLA, B.G.; ALVES, A.A.; ROSADO, T.B.; CRUZ, C.D. Differential response of Jatropha genotypes to different selection methods indicates that combined selection is more suited than other methods for rapid improvement of the species. Industrial Crops and Products, v.41, p.260-265, 2013. DOI: 10.1016/j. indcrop.2012.04.026.

CHAVES, A.R.M.; MARTINS, S.C.V.; BATISTA, K.D.; CELIN, E.F.; DAMATTA, F.M. Varying leaf-to-fruit ratios affect branch growth and dieback, with little to no effect on photosynthesis, carbohydrate or mineral pools, in different canopy positions of field-grown coffee trees. Environmental and Experimental Botany, v.77, p.207-218, 2012. DOI: 10.1016/j. envexpbot.2011.11.011.

DAMATTA, F.M.; CUNHA, R.L.; ANTUNES, W.C.; MARTINS, S.C.V.; ARAÚJO, W.L.; FERNIE, A.R.; MORAES, G.A.B.K. In field-grown coffee trees source-sink manipulation alters photosynthetic rates, independently of carbon metabolism, via alterations in stomatal function. New Phytologist, v.178, p.348357, 2008. DOI: 10.1111/j.1469-8137.2008.02367.x.

DAMATTA, F.M; GODOY, A.G. ; MENEZES-SILVA, P.E.; MARTINS, S.C.V.; SANGLARD, L.M.V.P.; MORAIS, L.E.; TORRE-NETO, A.; GHINI, R. Sustained enhancement of 
photosynthesis in coffee trees grown under free-air $\mathrm{CO}_{2}$ enrichment conditions: disentangling the contributions of stomatal, mesophyll, and biochemical limitations. Journal of Experimental Botany, v.67, p.341-352, 2016. DOI: 10.1093/jxb/erv463.

DÍAZ-LÓPEZ, L.; GIMENO, V.; SIMÓN, I.; MARTÍNEZ, V.; RODRÍGUEZ-ORTEGA, W.M.; GARCÍA-SÁNCHEZ, F. Jatropha curcas seedlings show a water conservation strategy under drought conditions based on decreasing leaf growth and stomatal conductance. Agricultural Water Management, v.105, p.48-56, 2012. DOI: 10.1016/j.agwat.2012.01.001.

DOMICIANO, G.P.; ALVES, A.A.; LAVIOLA, B.G.; ALBRECHT, J.C. Analysis of morpho-agronomic and climatic variables in successive agricultural years provides novel information regarding the phenological cycle of Jatropha in conditions of the Brazilian cerrado. Anais da Academia Brasileira de Ciências, v.86, p.1985-1998, 2014. DOI: 10.1590/0001-3765201420130226.

DURÃES, F.O.M.; LAVIOLA, B.G.; ALVES, A.A. Potential and challenges in making physic nut (Jatropha curcas L.) a viable biofuel crop: the Brazilian perspective. CAB Reviews: Perspectives in Agriculture, Veterinary Science, Nutrition and Natural Resources, v.6, p.1-8, 2011. DOI: 10.1079/ PAVSNNR20116043.

FAN, Y.; ZHONG, Z.; ZHANG, X. Determination of photosynthetic parameters $\mathrm{Vc}_{\max }$ and $\mathrm{J}_{\max }$ for a $\mathrm{C}_{3}$ plant (spring hulless barley) at two altitudes on the Tibetan Plateau. Agricultural and Forest Meteorology, v.151, p.1481-1487, 2011. DOI: 10.1016/j.agrformet.2011.06.004.

FARQUHAR, G.D.; SHARKEY, T.D. Stomatal conductance and photosynthesis. Annual Review of Plant Physiology, v.33, p.317345, 1982. DOI: 10.1146/annurev.pp.33.060182.001533.

GIBSON, K.; PARK, J.-S.; NAGAI, Y.; HWANG, S.-K.; CHO, Y.C.; ROH, K.-H.; LEE, S.-M.; KIM, D.-H.; CHOI, S.-B.; ITO, H.; EDWARDS, G.E.; OKITA, T.W. Exploiting leaf starch synthesis as a transient sink to elevate photosynthesis, plant productivity and yields. Plant Science, v.181, p.275-281, 2011. DOI: 10.1016/j. plantsci.2011.06.001.

GUCCI, R.; GRAPPADELLI, L.C.; TUSTIN, S.; RAVAGLIA, G. The effect of defruiting at different stages of fruit development on leaf photosynthesis of "Golden-Delicious" Apple. Tree Physiology, v.15, p.35-40, 1995.

GUPTA, A.K.; KAUR, N. (Ed.). Carbohydrate reserves in plants: synthesis and regulation. Amsterdam: Elsevier, 2000. (Developments in Crop Science, 26).

KAWAMITSU, Y.; YODA, S.; AGATA, W. Humidity pretreatment affects the responses of stomata and $\mathrm{CO}_{2}$ assimilation to vapor pressure difference in $\mathrm{C}_{3}$ and $\mathrm{C}_{4}$ plants. Plant and Cell Physiology, v.34, p.113-119, 1993. DOI: 10.1093/oxfordjournals.pcp.a078384.

LAVIOLA, B.G.; ALVES, A.A.; GURGEL, F. de D.; ROSADO, T.B.; ROCHA, R.B.; ALBRECHT, J.C. Estimates of genetic parameters for physic nut traits based in the germplasm two years evaluation. Ciência Rural, v.42, p.429-435, 2012. DOI: 10.1590/ S0103-84782012000300008.

LAVIOLA, B.G.; DIAS, L.A. dos S. Teor e acúmulo de nutrientes em folhas e frutos de pinhão-manso. Revista Brasileira de
Ciência do Solo, v.32, p.1969-1975, 2008. DOI: 10.1590/S010006832008000500018 .

LEGROS, S.; MIALET-SERRA, I.; CLEMENT-VIDAL, A.; CALIMAN, J.-P. SIREGAR, F. -A.; FABRE, D.; DINGKUHN, M. Role of transitory carbon reserves during adjustment to climate variability and source-sink imbalances in oil palm (Elaeis guineensis). Tree Physiology, v.29, p.1199-1211, 2009. DOI: 10.1093/ treephys/tpp057.

LI, W.D.; DUAN, W.; FAN, P.G.; YAN, S.T.; LI, S.H. Photosynthesis in response to sink-source activity and in relation to end products and activities of metabolic enzymes in peach trees. Tree Physiology, v.27, p.1307-1318, 2007. DOI: 10.1093/treephys/27.9.1307.

MOHAPATRA, S.; PANDA, P.K. Genetic variability on growth, phenological and seed characteristics of Jatropha curcas L. Notulae Scientia Biologicar, v.2, p.127-132, 2010.

PAUL, M.J.; FOYER, C.H. Sink regulation of photosynthesis. Journal of Experimental Botany, v.52, p.1383-1400, 2001. DOI: 10.1093/jexbot/52.360.1383.

PROIETTI, P. Effect of fruiting on leaf gas exchange in olive (Olea europaea L.). Photosynthetica, v.38, p.397-402, 2000. DOI: 10.1023/A:1010973520871.

RAJAONA, A.M.; BRUECK, H.; ASCH, F. Leaf gas exchange characteristics of jatropha as affected by nitrogen supply, leaf age and atmospheric vapour pressure deficit. Journal of Agronomy and Crop Science, v.199, p.144-153, 2013. DOI: 10.1111/jac.12000.

RANJAN, S.; SINGH, R.; SONI, D.K.; PATHRE, U.V.; SHIRKE, P.A. Photosynthetic performance of Jatropha curcas fruits. Plant Physiology and Biochemistry, v.52, p.66-76, 2012. DOI: 10.1016/j. plaphy.2011.11.008.

SANTOS, C.M. dos; VERÍSSIMO, V.; WANDERLEY FILHO, H.C. de L.; FERREIRA, V.M.; CAVALCANTE, P.G. da S.; ROLIM, E.V.; ENDRES, L. Seasonal variations of photosynthesis, gas exchange, quantum efficiency of photosystem II and biochemical responses off Jatropha Curcas L. grown in semi-humid and semi-arid areas subject to water stress. Industrial Crops and Products, v.41, p.203213, 2013. DOI: 10.1016/j.indcrop.2012.04.003.

SHARKEY, T.D.; BERNACCHI, C.J.; FARQUHAR, G.D.; SINGSAAS, E.L. Fitting photosynthetic carbon dioxide response curves for $\mathrm{C}_{3}$ leaves. Plant Cell and Environment, v.30, p.10351040, 2007. DOI: 10.1111/j.1365-3040.2007.01710.x.

SILVA, E.N.; RIBEIRO, R.V.; FERREIRA-SILVA, S.L.; VIEIRA, S.A.; PONTE, L.F.A.; SILVEIRA, J.A.G. Coordinate changes in photosynthesis, sugar accumulation and antioxidative enzymes improve the performance of Jatropha curcas plants under drought stress. Biomass and Bioenergy, v.45, p.270-279, 2012. DOI: 10.1016/j. biombioe.2012.06.009.

SILVA, P.E.M.; CAVATTE, P.C.; MORAIS, L.E.; MEDINA, E.F.; DAMATTA, F.M. The functional divergence of biomass partitioning, carbon gain and water use in Coffea canephora in response to the water supply: implications for breeding aimed at improving drought tolerance. Environmental and Experimental Botany, v.87, p.49-57, 2013. DOI: 10.1016/j.envexpbot.2012.09.005.

URBAN, L.; JEGOUZO, L.; DAMOUR, G.; VANDAME, M.; FRANÇOIS, C. Interpreting the decrease in leaf photosynthesis 
during flowering in mango. Tree Physiology, v.28, p.1025-1036, 2008. DOI: 10.1093/treephys/28.7.1025.

URBAN, L.; LÉCHAUDEL, M. Effect of leaf-to-fruit ratio on leaf nitrogen content and net photosynthesis in girdled branches of Mangifera indica L. Trees, v.19, p.564-571, 2005. DOI: 10.1007/ s00468-005-0415-6.

URBAN, L.; LÉCHAUDEL, M.; LU, P. Effect of fruit load and girdling on leaf photosynthesis in Mangifera indica L. Journal of Experimental Botany, v.55, p.2075-2085, 2004. DOI: 10.1093/ $\mathrm{jxb} / \mathrm{erh} 220$.
WULLSCHLEGER, S.D. Biochemical limitations to carbon assimilation in $\mathrm{C}_{3}$ plants - a retrospective analysis of the $\mathrm{A} / \mathrm{Ci}$ curves from 109 species. Journal of Experimental Botany, v.44, p.907-920, 1993. DOI: 10.1093/jxb/44.5.907.

ZHENG, Y.-L.; FENG, Y.-L.; LEI, Y.-B.; YANG, C.-Y. Different photosynthetic responses to night chilling among twelve populations of Jatropha curcas. Photosynthetica, v.47, p.559566, 2009. DOI: 10.1007/s11099-009-0081-9.

$\overline{\text { Received on April 14, } 2016 \text { and accepted on June 2, } 2017}$ 